\title{
Inhibition of NET-1 suppresses proliferation and promotes apoptosis of hepatocellular carcinoma cells by activating the PI3K/AKT signaling pathway
}

\author{
XIANGJUN SUN ${ }^{1}$, MINGCHUN WANG $^{2}$, FENGHUA ZHANG $^{2}$ and XIAO KONG ${ }^{1}$ \\ Departments of ${ }^{1}$ Hepatobiliary Surgery and ${ }^{2}$ Surgery, Linyi People's Hospital, \\ Linyi, Shandong 276003, P.R. China
}

Received June 22, 2017; Accepted July 20, 2018

DOI: $10.3892 /$ etm.2019.7211

\begin{abstract}
The present study aimed to elucidate the underlying mechanism of neuroepithelial cell transforming 1 (NET-1), a member of the Ras homolog gene family, in hepatocellular carcinoma (HCC). To determine the association between the expression of NET-1 and the proliferation and migration of MHCC97-H cells, the cells were transfected with NET-1 small interfering (si)RNA and si negative control. Following transfection with NET-1 siRNA, the proliferation rate of MHCC97-H cells decreased significantly and the percentage of apoptotic cells increased. The HCC cell line MHCC97-H was used in the present study as it exhibited an increased expression level of NET-1 compared with the MHCC97-L cell line. Expression levels of apoptosis-associated proteins including apoptosis regulator $\mathrm{Bax}(\mathrm{Bax})$, cyclinD1, apoptosis regulator $\mathrm{Bcl}-2$ (Bcl-2) and caspase-3 were determined. Expression levels of phosphoinositide 3-kinase (PI3K) and protein kinase B (AKT) and their phosphorylated forms were also measured by western blotting. Following NET-1 knockdown, the expression of Bax and cyclinD1 decreased, the expression of Bcl-2 and caspase- 3 increased, and the PI3K/AKT signaling pathway was inhibited. The results of the present study suggest that inhibition of NET-1 can suppress the progression of HCC by targeting the $\mathrm{PI} 3 \mathrm{~K} / \mathrm{AKT}$ signaling pathway. NET-1 expression level in HCC cells increased compared with normal liver cells.
\end{abstract}

\section{Introduction}

Hepatocellular carcinoma (HCC) is one of the common malignant tumors worldwide (1). Globally, there are more than 500,000 new cases each year and about 1 million HCC-associated cases

Correspondence to: Dr Mingchun Wang, Department of Surgery, Linyi People's Hospital, Surgery Building, 27 Jiefang East Road, Linyi, Shandong 276003, P.R. China

E-mail: mingchunwang_2@163.com

Key words: neuroepithelial cell transforming 1, hepatocellular carcinoma, proliferation, phosphoinositide 3-kinase, protein kinase $\mathrm{B}$ of mortality (2-6). Approximately 40-50\% of global HCC cases occur in China and HCC is the second most malignant tumor in China (7-10). Although there are a number of methods of treatment for HCC, they are ineffective for achieving sustained remission (11). Invasion, metastasis and postoperative recurrence are the primary causes leading to the mortality of patients with HCC (12). The processes associated with invasion and metastasis of HCC are complex and involve multiple molecular interactions and multiple-level cross regulation of signal transduction pathways $(13,14)$. Therefore, research on the mechanisms of invasion and metastasis of HCC is important to increase the clinical curative effects and improve the survival rate of patients.

Neuroepithelial cell transforming 1 (NET-1), a member of Ras homolog gene family, was identified in 2000 by Serru et al (15) and reported to serve a role in signaling pathways, including ERK1/2 and PI3K/Akt1, which may be regulated by NET-1 as well as cell adhesion, proliferation and differentiation $(16,17)$. A study also demonstrated that the inhibition of NET-1 could suppress the activation of ERK1/2 and PI3K/Akt1 signaling (18). Previous studies also indicated that the abnormal expression of NET-1 is associated with numerous types of cancer, including lung, colorectal, gastric and breast cancer $(19,20)$. Shen et al (21) reported that NET-1 mRNA is expressed at very low levels in normal liver tissues and highly expressed in HCC tissues, suggesting that this protein may serve as a biomarker in the early diagnosis of liver cancer. Expression of NET-1 is closely associated with the lymphatic and distant metastasis in non-small cell lung cancer (22). One study revealed that inhibition of NET-1 in HCC was associated with the tumor node metastasis stage (23). Therefore, the authors of the present study hypothesized that NET-1 may serve an important role in HCC.

The present study aimed to determine the association between the expression of NET-1 and HCC. The mRNA expression levels of NET-1 in HCC cell lines and a normal liver cell line were compared and the cell line with the highest expression level of NET-1 was selected. The selected cells were transfected with NET-1 small interfering (si)RNA and si negative control (NC), and the proliferation rate and apoptosis of cells were determined. The expression of apoptosis-associated proteins was also determined to elucidate the molecular mechanism of NET-1 in HCC. 


\section{Materials and methods}

Cell culture. Human HCC cell lines MHCC97-L and MHCC97-H, and a normal liver cell line L-02 were obtained from the Cell Bank of Type Culture Collection of Chinese Academy of Sciences (Shanghai, China). The cell lines stored in $-80^{\circ} \mathrm{C}$ liquid nitrogen was recovered, inoculated, cultured and digested to obtain single cell suspension. Cells were routinely cultured in RPMI-1640 supplemented with $10 \%$ heat-inactivated fetal bovine serum (Thermo Fisher Scientific, Inc., Waltham, MA, USA), $100 \mathrm{U} / \mathrm{ml}$ penicillin and $100 \mu \mathrm{g} / \mathrm{ml}$ streptomycin in a humidified cell incubator with an atmosphere of $5 \% \mathrm{CO}_{2}$ at $37^{\circ} \mathrm{C}$.

RNA isolation and reverse transcription-quantitative polymerase chain reaction $(R T-q P C R)$. Total RNA was extracted from cell lines using TRIzol reagent (Thermo Fisher Scientific, Inc.) according to the manufacturer's protocol. Briefly, $1 \mathrm{ml}$ of TRIzol was added and each sample was homogenized at $4^{\circ} \mathrm{C}$ for $10 \mathrm{~min}$. Subsequently, the lysates were transferred into $1.5 \mathrm{ml}$ Eppendorf (EP) tubes (Eppendorf, Hamburg, Germany). Following shaking for $15 \mathrm{~min}$, the EP tubes were centrifuged at $12,000 \mathrm{x} \mathrm{g}$ and $4^{\circ} \mathrm{C}$ for $15 \mathrm{~min}$. The supernatant was transferred into new EP tubes and mixed with isopycnic isopropanol for $15 \mathrm{sec}$. Subsequently, the mixture was centrifuged at $12,000 \mathrm{x} \mathrm{g}$ and $4^{\circ} \mathrm{C}$ for $10 \mathrm{~min}$, and the supernatant was discarded. The precipitate was washed with $75 \%$ ethanol twice and dried. Then, the dried precipitate was dissolved in $30 \mu \mathrm{l}$ DEPC-treated $(0.1 \%)$ water (Thermo Fisher Scientific, Inc.) and quantified by a NanoDrop 1000 spectrophotometer (NanoDrop; Thermo Fisher Scientific, Inc., Wilmington, Delaware, USA) and the RNA solution was stored at $-80^{\circ} \mathrm{C}$ for further use. Genes were amplified using specific oligonucleotide primers for NET-1 and GAPDH, which was used as the internal control. The forward and reverse primers are listed in Table I. The first strand of cDNA was synthesized by RevertAid First strand cDNA Synthesis kit (Thermo Fisher Scientific, Inc.) at $42^{\circ} \mathrm{C}$ for $10 \mathrm{~min}$. SYBR ${ }^{\circledR}$ Green Real-Time PCR Master mixes (Takara Bio, Inc., Otsu, Japan) and a LightCycler ${ }^{\circledR} 480$ System (Roche Diagnostics, Basel, Switzerland) were utilized to perform a qPCR analysis. The following thermocycling conditions were used for the PCR: $55^{\circ} \mathrm{C}$ for $30 \mathrm{~min}$, initial denaturation for $15 \mathrm{~min}$ at $95^{\circ} \mathrm{C}$; 40 cycles of $94^{\circ} \mathrm{C}$ for $15 \mathrm{sec}, 55^{\circ} \mathrm{C}$ for $30 \mathrm{sec}, 72^{\circ} \mathrm{C}$ for $30 \mathrm{sec}$. The expression level was normalized using GAPDH small nuclear RNA and expression levels were quantified using the $2^{-\Delta \Delta \mathrm{Cq}}$ method (23).

Western blotting. Cells were seeded into a six-well plate at a density of $5 \times 10^{5}$ cells/well. A total of $24 \mathrm{~h}$ after seeding, the medium was discarded and cells were rinsed 3 times with ice-cold PBS. Subsequently, cells were lysed with radioimmunoprecipitation assay buffer at $4^{\circ} \mathrm{C}$ for $15 \mathrm{~min}$ and centrifuged at $12,000 \mathrm{x} \mathrm{g}$ at $4^{\circ} \mathrm{C}$ for $10 \mathrm{~min}$. The precipitation was discarded and the protein extract in the supernatant was quantified by a BCA kit (Thermo Fisher Scientific, Inc.). The supernatants were collected and boiled at $95^{\circ} \mathrm{C}$ with an equal volume of loading buffer for $10 \mathrm{~min}$. Subsequently, a total of $12 \mu \mathrm{g}$ of protein was loaded into $4 \%$ spacer and $12 \%$ separation gel for SDS-PAGE, and transferred to polyvinylidene difluoride membranes (Hybond, Inc., Escondido, CA, USA). The membranes were blocked with $5 \%$ skimmed milk dissolved in Tris-buffered saline Tween-20 (TBST) for $1 \mathrm{~h}$ at room temperature. Subsequently, the membranes were rinsed with TBST twice and incubated with primary antibodies, including NET-1 (cat. no. ab5914), Bax (cat. no. ab32503), Cyclin D1 (cat. no. ab134175), Bcl-2 (cat. no. ab32124), Caspase-3 (cat. no. ab13585), PI3K (cat. no. ab86714), p-PI3K (cat. no. ab182651), AKT (cat. no. ab8805), p-AKT (cat. no. ab81283) and GAPDH (cat. no. ab9485; all 1:1,000; Abcam, Cambridge, MA, USA) dissolved in 5\% bovine serum albumin (Abcam) at room temperature for $1 \mathrm{~h}$. Membranes were then incubated with the horseradish peroxidase-conjugated secondary antibodies (cat.no. ab6721; 1:10,000, Abcam) at room temperature for $1 \mathrm{~h}$. Protein bands were visualized using the EZ-ECL Chemiluminescence Detection kit for horseradish peroxidase (Biological Industries, Kibbutz Beit Haemek, Israel).

Cell transfection. A total of $1 \times 10^{3}-1 \times 10^{4}$ cells/well were seeded in 96-well plates. NET-1 overexpression or control vector plasmids $(0.2 \mu \mathrm{g}$; both Genentech USA, Inc., South San Francisco, CA, USA) were transfected into cells using Lipofectamine ${ }^{\circledR} 2000$ transfection reagent (Invitrogen; Thermo Fisher Scientific, Inc., Waltham, MA, USA) according to the manufacturer's protocol. The NET-1 siRNA or scramble control siNC (10 pmol) was synthesized and modified chemically by Invitrogen (Thermo Fisher Scientific, Inc.) using Lipofectamine $^{\mathrm{TM}}$ RNAiMAX (Thermo Fisher Scientific, Inc.). Following $72 \mathrm{~h}$ of transfection, cells were harvested for proliferation and apoptosis assays.

Flow cytometry assay. Apoptosis and cell cycle of MHCC97-H cells were detected using flow cytometry kit (cat. no. Apobrdu-1KT; Sigma-Aldrich; Merck KGaA, Darmstadt, Germany). Briefly, MHCC97-H cells at a logarithmic growth phase were seeded in a 96-well plate at a density of $2 \times 10^{3}$ cells/well and maintained in RPMI 1640 medium (cat. no. SH30809.01; Invitrogen; Thermo Fisher Scientific, Inc.) with $10 \%$ fetal bovine serum (cat. no. AD17321268; Invitrogen; Thermo Fisher Scientific, Inc.) for $16 \mathrm{~h}$ at $37^{\circ} \mathrm{C}$. Following cell transfection with control plasmids, control siRNA or NET-1-siRNA for $72 \mathrm{~h}$, the cells were rinsed twice

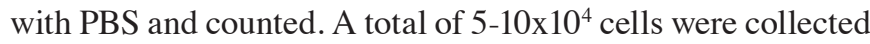
and centrifuged at 2,000 $\mathrm{x}$ g for $5 \mathrm{~min}$ at $4^{\circ} \mathrm{C}$. Subsequently, cells were resuspended with and incubated for additional $10 \mathrm{~min}$ at $37^{\circ} \mathrm{C}$. Centrifugation at $2,000 \mathrm{x} \mathrm{g}$ for $5 \mathrm{~min}$ at $4^{\circ} \mathrm{C}$ was performed and the cells were resuspended in PBS containing $10 \mu \mathrm{l}$ propidium iodide in the dark for $30 \mathrm{~min}$ at room temperature. Finally, apoptosis was measured using a flow cytometer and CellQuest software (version 3.3; BD Biosciences, San Jose, CA, USA).

Cell proliferation assay. Cells were seeded into 96-well plates at a density of $5 \times 10^{4}$ cells/well the day prior to transfection. Following transfection, cells were seeded in a 96-well plate at a density of $2 \times 10^{3}$ cells/well. Proliferation of cells was determined using Cell Counting kit-8 (CCK-8; Dojindo Molecular Technologies, Inc., Kumamoto, Japan) according to 
Table I. Primer sequences for reverse transcription-quantitative polymerase chain reaction.

Primer sequences $\left(5^{\prime}-3^{\prime}\right)$

\begin{tabular}{lll}
\cline { 2 - 3 } Gene name & \multicolumn{1}{c}{ Forward } & \multicolumn{1}{c}{ Reverse } \\
\hline Neuroepithelial cell transforming 1 & GAGCCAAGCAATAAAAGAGTTCG & TGGGACTGTTGACCTGCTAGA \\
GAPDH & GGAGCGAGATCCCTCCAAAAT & GGCTGTTGTCATACTTCTCATGG
\end{tabular}

A

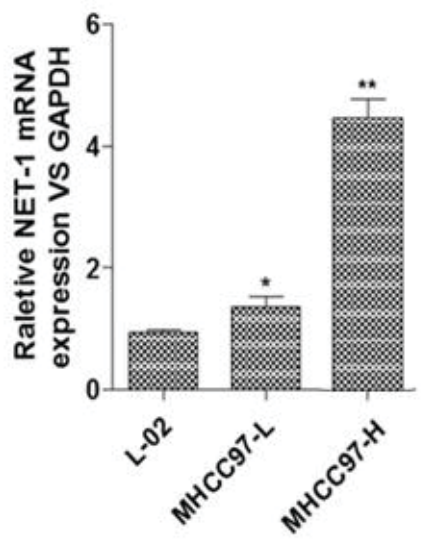

B

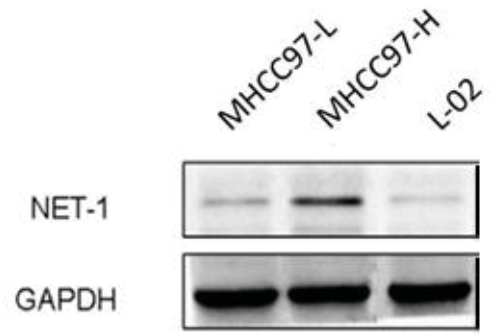

Figure 1. NET-1 expression in HCC cell lines and normal liver cells. (A) Relative mRNA expression levels of NET-1 in HCC cell lines MHCC97-L and MHCC97-H, and normal liver cell line L-02 were determined by reverse transcription-quantitative polymerase chain reaction. ${ }^{*} \mathrm{P}<0.05$ and ${ }^{* *} \mathrm{P}<0.01$ vs. the L-02 cells. (B) Protein expression levels of NET-1 in HCC cell lines MHCC97-L and MHCC97-H, and normal liver cell line L-02 were determined by western blotting. NET-1, neuroepithelial cell transforming 1; HCC, hepatocellular carcinoma.

the manufacturer's protocol at 12, 24 and $48 \mathrm{~h}$ of culture. The optical density (OD) was measured at a wavelength of $450 \mathrm{~nm}$.

Statistical analysis. Data were analyzed using SPSS software (version 19.0; IBM Corp., Armonk, NY, USA). All data are presented as the mean \pm standard deviation. All experiments were performed in triplicate. Groups were compared using one-way analysis of variance followed by Tukey's post hoc test. $\mathrm{P}<0.05$ was considered to indicate a statistically significant difference.

\section{Results}

Screening for HCC cells with high expression of NET-1. To study the effect of NET-1 on HCC, the present study determined the relative mRNA and protein expression levels of NET-1 in HCC cell lines MHCC97-L and MHCC97-H and in a normal liver cell line L-02 using RT-qPCR and western blotting, respectively. The results of the RT-qPCR assay indicated that the expression levels of NET-1 were significantly elevated in MHCC97-L and MHCC97-H cells compared with the L-02 cell line. Specifically, the MHCC97-H cell line exhibited the highest expression of NET-1 among these cell lines (Fig. 1A). Furthermore, western blotting indicated that protein expression of NET-1 increased in MHCC97-L and MHCC97-H cells compared with the L-02 cell line, and MHCC97-H exhibited the highest expression level among these cell lines (Fig. 1B). Therefore, MHCC97-H cells were selected for further analysis.

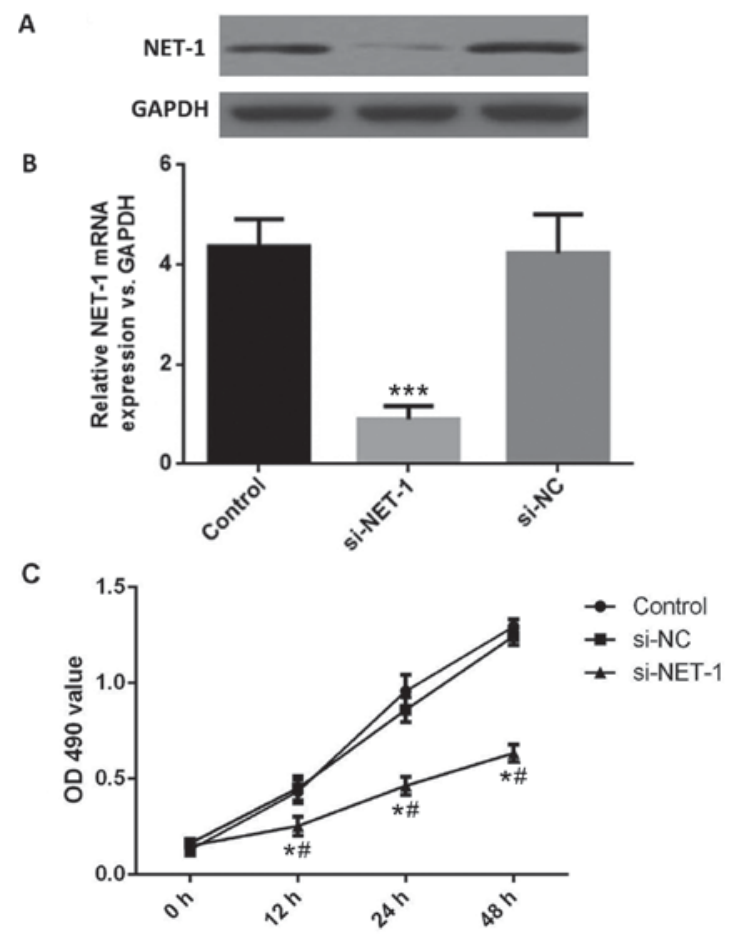

Figure 2. Verification of transfection efficiency and cell proliferation assays. (A) Protein and (B) mRNA expression of NET-1 in differentially treated cells. (C) The OD 490 value of MHCC97-H cells following transfection with NET-1 siRNA or siNC. ${ }^{*} \mathrm{P}<0.05,{ }^{* * *} \mathrm{P}<0.001$ vs. control; ${ }^{\#} \mathrm{P}<0.05$ vs. si-NC. NET-1, neuroepithelial cell transforming 1; si, small interfering RNA; si-NC, small interfering RNA negative control. 

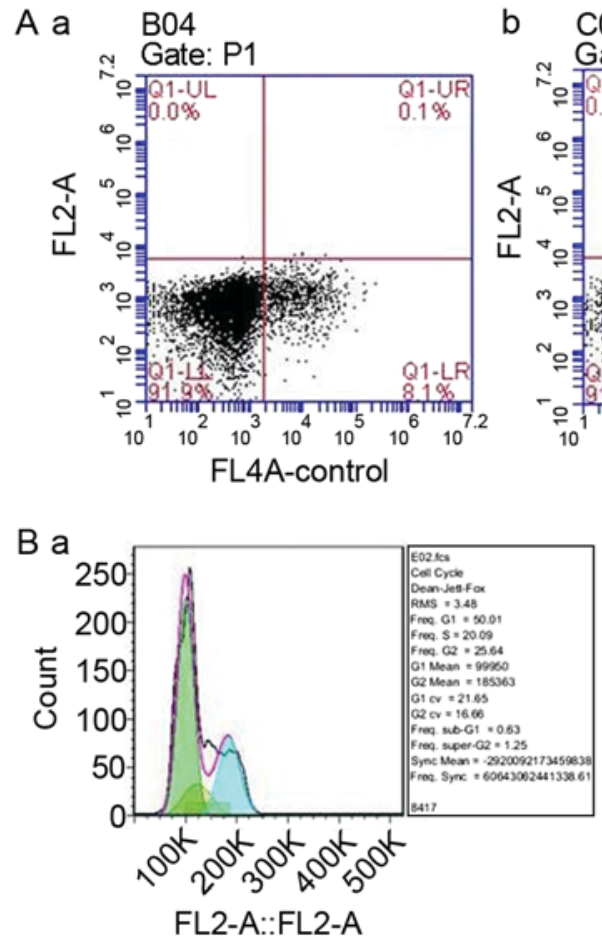

Control

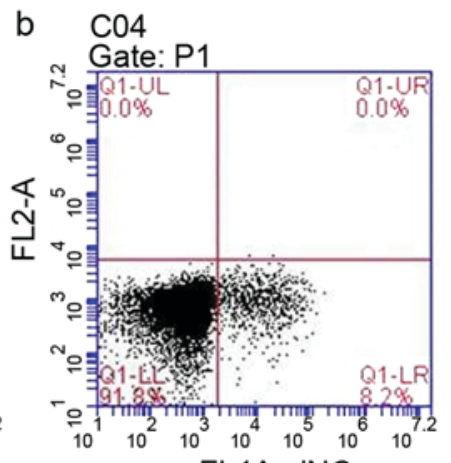

FL4A-siNC
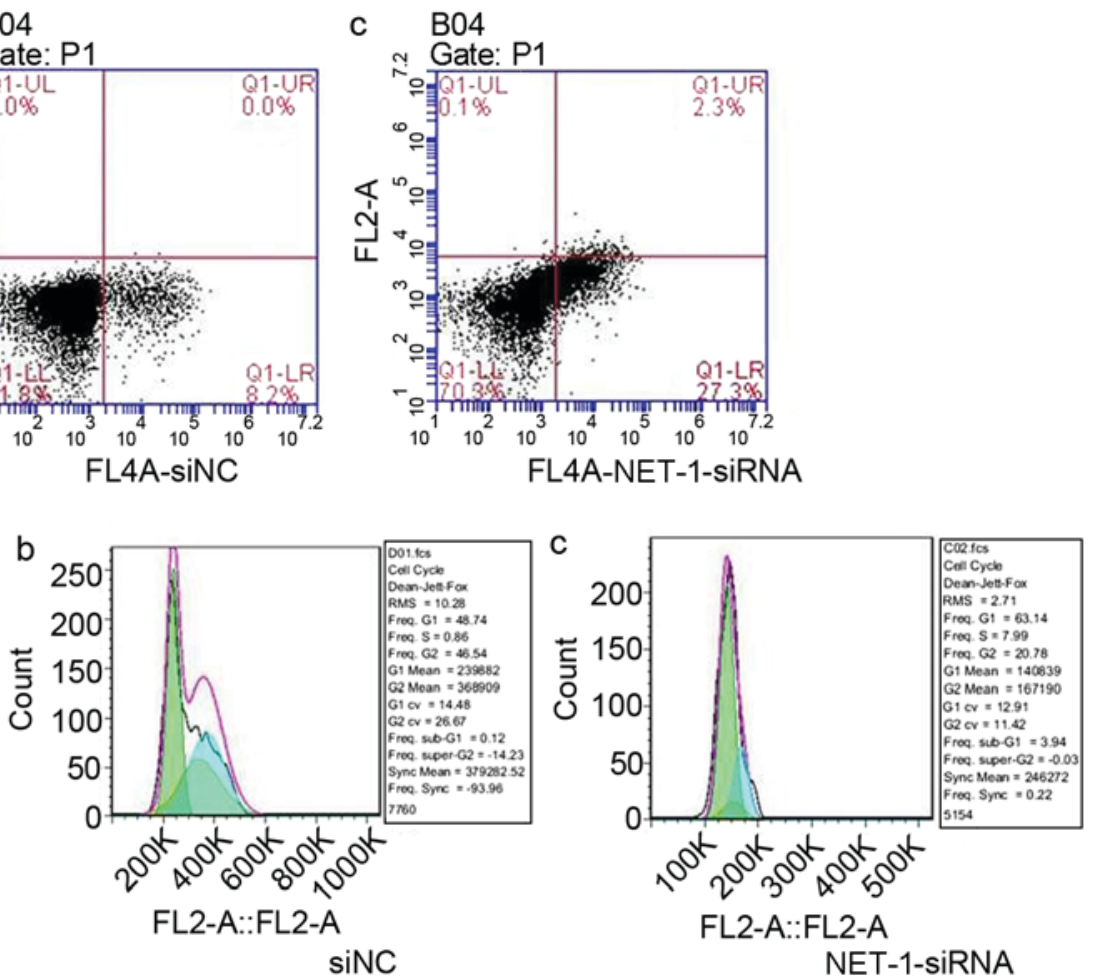

Figure 3. Knockdown of NET-1 promotes hepatocellular carcinoma cell apoptosis. (A) Apoptotic percent of MHCC97-H cells in the (a) control, (b) siNC and (c) NET-1 siRNA groups. (B) Cell cycle distribution of MHCC97-H cells in the (a) control, (b) siNC and (c) NET-1 siRNA. siRNA, small interfering RNA; siNC, small interfering RNA negative control; NET-1, neuroepithelial cell transforming 1.

Knockdown of NET-1 inhibited the proliferation of HCC cells. Following transfection with si-NET-1, the mRNA and protein expression of NET-1 was successfully downregulated in cells compared with the control (Fig. 2A and B). The OD value of MHCC 97-H cells was determined by CCK- 8 . The viability of MHCC97-H cells in the si-NET-1 group was significantly decreased after 12, 24 and $48 \mathrm{~h}$ compared with the control groups (Fig. 2C), suggesting the inhibition of NET-1 could inhibit the proliferation of HCC.

Knockdown of NET-1 promotes HCC cell apoptosis. To study the effect of NET-1 on HCC, the apoptotic rate and cell cycle of MHCC 97-H cells were determined using flow cytometry. The apoptotic percent of MHCC97-H cells increased following the knockdown of NET-1 compared with the control and si-NC groups (Fig. 3A). Furthermore, cell cycle of MHCC97-H cells was arrested at the G1/S phase following transfection with NET-1 siRNA (Fig. 3B).

KnockdownofNET-1 influences the expressionofapoptosis-associated proteins and the activity of the PI3K/AKT signaling pathway. To further reveal the underlying mechanism of NET-1 in HCC, expression levels apoptosis-associated proteins were determined by western blotting. The expression levels of Bax and cyclinD1 in MHCC97-H cells decreased following the knockdown of NET-1, while the expression of Bcl-2 and caspase-3 increased (Fig. 4A). The activity of the PI3K/AKT signaling pathway was also determined when PI3K expression was reduced by the NET-1 siRNA. There was no apparent difference identified in the activity of PI3K, however, the expression of p-AKT decreased following transfection with si-NET-1 (Fig. 4B).

\section{Discussion}

HCC is the most common type of primary liver cancer and has been reported to be the fifth most common cancer worldwide (10). The incidence of HCC has increased worldwide and this disease is characterized by geographic risk factor and diagnosis differences (24). There remains no standard effective therapy for patients with HCC. This type of carcinoma is associated with a high degree of vascular invasion and metastasis, and poor prognosis (25). Numerous factors contribute to the invasion and metastasis of HCC. Twist-related protein 1 is a regulator of EMT-mediated invasion and metastasis, which affects the expression of E-cadherin (26). As a pro-inflammatory cytokine, interleukin (IL)-17A is frequently involved in the pathology of inflammatory diseases and regulation of tumor microenvironment (27-29). A previous study reported that IL-17A promoted the metastasis of HCC (30). As a tumor suppressor, microRNA-122 was reported to regulate the intrahepatic metastasis of HCC (31). It has also been demonstrated that NET-1 exhibits higher expression levels in HCC cells compared with normal liver cells, suggesting that NET-1 may serve a role in HCC (21).

In the present study, the mechanism of NET-1 in the invasion and metastasis of HCC was investigated in vitro. Relative mRNA expression of NET-1 was determined using RT-qPCR in MHCC97-H and MHCC97-L cells with different metastasis potentials $(32,33)$ and normal liver cell line L-02. The results indicated that the expression of NET-1 was upregulated in HCC cell lines compared with the normal liver cell line, which may contribute to the metastasis and invasion of HCC. The MHCC97-H cell line exhibited the highest expression level 
A

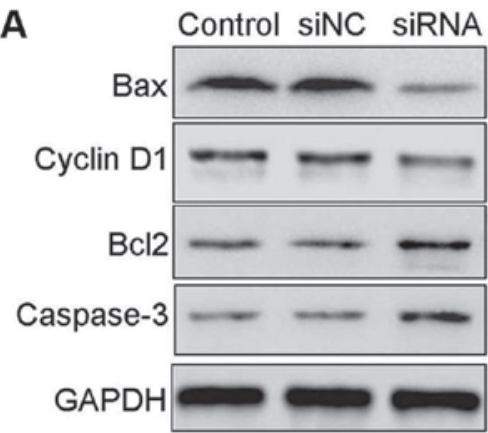

C

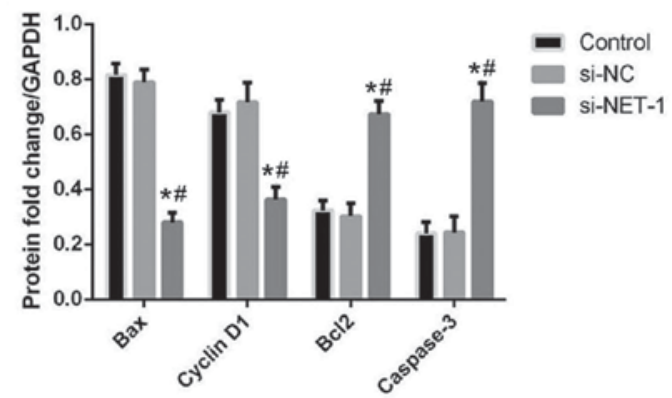

B

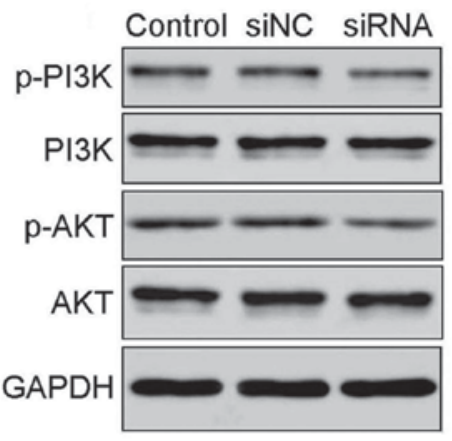

D

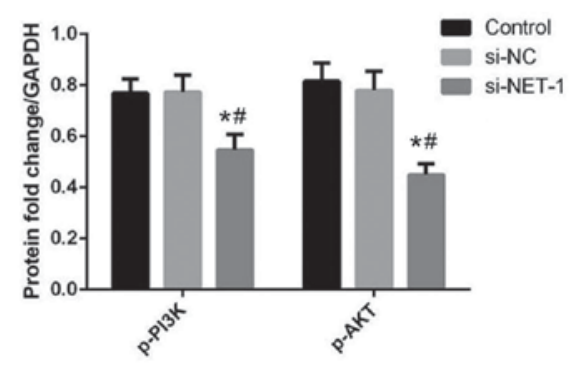

Figure 4. Knockdown of NET-1 influences the expression of apoptosis-associated proteins and the activity of the PI3K/AKT signaling pathway. (A) Protein expression of Bax, cyclinD1, Bcl-2 and caspase-3. (B) Protein expression of p-PI3K, PI3K, p-AKT and AKT. (C) Quantification of the protein levels of Bax, cyclinD1, Bcl-2 and caspase-3. (D) Quantification of the protein levels of p-PI3K and p-AKT. " $\mathrm{P}<0.05$ vs. control; " $\mathrm{P}<0.05$ vs. siNC. Bax, apoptosis regulator Bax; Bcl-2, apoptosis regulator Bcl-2; PI3K, phosphoinositide 3-kinase; AKT, protein kinase B; siNC, small interfering RNA negative control; siRNA, small interfering RNA targeting neuroepithelial cell transforming 1.

of NET-1 and was therefore selected for subsequent experiments. NET-1 was knocked down in MHCC97-H cells and proliferation, cell cycle progression and apoptosis were determined. The results indicated that si-NET-1 could decrease the proliferation of MHCC97-H cells. Furthermore, the apoptotic percent of MHCC97-H cells was elevated following the knockdown of NET-1. In addition, cell cycle was arrested at the G1/S phase in the si-NET-1 group of MHCC97-H cells. Shen et al (21) demonstrated that the expression of NET-1 was associated with the proliferation, metastasis and clinical stages of HCC. Chen et al (34) reported a strong correlation between the expression level of NET-1 and HCC pathological grading. Therefore, in the present study it was hypothesized that NET-1 may serve a role in promoting proliferation and suppressing apoptosis of HCC.

To further elucidate the molecular mechanisms of NET-1, the expressions levels of Bax, cyclinD1, Bcl-2 and caspase-3 were determined. The expression levels of Bax and cyclinD1 decreased in the si-NET-1 MHCC97-H cells, while the expression levels of Bcl-2 and caspase- 3 increased compared with the controls. As a pro-apoptotic member of the Bcl-2 family, Bax shares highly conserved domains with $\mathrm{Bcl}-2$ and serves a role in regulating programmed cell death (35). Dysfunction of the $\mathrm{p} 53 / \mathrm{Bax} / \mathrm{caspase}-3$ apoptosis signaling pathway promotes carcinogenesis (36). Furthermore, a balance between Bax and Bcl-2 is also involved in cancer therapeutic resistance (37), as well as proliferation, invasion, adhesion and metastasis of cancer cells (38). In a human breast cancer line, overexpression of Bcl-2 enhanced the metastatic ability (39). Cyclin D1 is a proto-oncogene abnormally overexpressed in several cancers, including breast and prostate cancers, which promotes cell proliferation via activation of cyclin-dependent kinases (40). Cyclin D1 may act as a subunit of a holoenzyme to phosphorylate and inactivate the retinoblastoma protein, and promote cell cycle progression to the $G_{2}$ phase of the cell cycle (41). Apoptosis is an important mechanism of cell death regulation which serves a role in eliminating infected, damaged and other undesirable cells from tissues $(42,43)$. Caspase- 3 is the main executor of apoptosis in cells (44). During programmed cell death, activation of caspase-3 leads to proteolysis of DNA repair proteins and cytoskeletal proteins to alter the morphology and DNA of cells (45). Dysregulation of caspase-3 was reported in several malignancies (46-48) and overexpression of this protein was reported in HCC (49).

To further explore the molecular mechanism of NET-1 in $\mathrm{HCC}$, the activity of the PI3K/AKT signaling pathway was determined. The results indicated that there was no apparent difference identified in the expression of PI3K, however, the expression of AKT was downregulated following knockdown of NET-1. The PI3K/AKT signaling pathway serves an important role in mediating survival signals in a number of neuronal cell types (50). AKT and AKT-dependent signaling pathways, including glycogen synthase kinase-3 $\beta$ (51), PI3K (52) and mitogen-activated protein kinase (53) signaling pathways serve critical roles in the pathogenesis of degenerative diseases and cancers (51), including apoptosis, metabolism, cell proliferation and cell growth (50). Epidemiological and experimental studies reported that abnormally activated PI3K/AKT pathway is involved in the initiation and maintenance of cancer (52-55). In addition, the PI3K/AKT signaling pathway has also been 
confirmed to participate in leptin-mediated promotion of invasion and migration of HCC (56). Therefore, these studies verified the reasons why NET-1 promotes proliferation and inhibits apoptosis of HCC cells.

In conclusion, inhibition of NET-1 can suppress proliferation and promote apoptosis of HCC cells by activating the $\mathrm{PI} 3 \mathrm{~K} / \mathrm{AKT}$ signaling pathway and increasing the expression levels of apoptosis-associated proteins.

\section{Acknowledgements}

Not applicable.

\section{Funding}

The current study was supported by the Key Development Projects in Shandong (grant no. 2018GSF118191) and Shandong Medical Science and Technology Development Program (grant no. 2017WS321).

\section{Availability of data and materials}

All data and materials in the present study were available when proper request to the authors.

\section{Authors' contributions}

XS conceived of and designed the present study, collected and consolidated the data, analyzed and interpreted the data, and wrote the manuscript. MW conceived of and designed the current study, and collected and consolidated the data. FZ conceived of and designed the current study, analyzed and interpreted the data, and wrote the manuscript. XK conceived of and designed the current study, analyzed and interpreted the data, and wrote the manuscript.

\section{Ethics approval and consent to participate}

Ethical approval for cell culturing was given by the Medical Ethics Committee of Linyi People's Hospital.

\section{Patient consent for publication}

Not applicable.

\section{Competing interests}

The authors declare that they have no competing interests.

\section{References}

1. Keeffe EB: Risk score for development of HCC: Ready for use in practice? Lancet Oncol 12: 517-519, 2011.

2. Furihata T, Sawada T, Kita J, Iso Y, Kato M, Rokkaku K, Shimoda M and Kubota K: Serum alpha-fetoprotein level per tumor volume reflects prognosis in patients with hepatocellular carcinoma after curative hepatectomy. Hepatogastroenterology 55: 1705-1709, 2008.

3. Kütting F, Schubert J, Franklin J, Bowe A, Hoffmann V, Demir M, Pelc A, Nierhoff D, Töx U and Steffen HM: Insufficient evidence of benefit regarding mortality due to albumin substitution in HCC-free cirrhotic patients undergoing large volume paracentesis. J Gastroenterol Hepatol 32: 327-338, 2017.
4. Sasaki K, Firl DJ, Hashimoto K, Fujiki M, Diago-Uso T, Quintini C, Eghtesad B, Fung JJ, Aucejo FN and Miller CM: Development and validation of the HALT-HCC score to predict mortality in liver transplant recipients with hepatocellular carcinoma: A retrospective cohort analysis. Lancet Gastroenterol Hepatol 2: 595-603, 2017.

5. Schwarz L, Bubenheim M, Zemour J, Herrero A, Muscari F, Ayav A, Riboud R, Ducerf C, Regimbeau JM, Tranchart H, et al: Bleeding recurrence and mortality following interventional management of spontaneous HCC rupture: Results of a multicenter European study. World J Surg 42: 225-232, 2018.

6. Sun LY, Zhang H, Li ZL, Li C, Wang MD and Yang T: How to predict global trends in $\mathrm{HCC}$ mortality if neglecting more than half the world's cases? J Hepatol 67: 887-888, 2017.

7. Cao W, Li J, Hu C, Shen J, Liu X, Xu Y and Ye Z: Symptom clusters and symptom interference of $\mathrm{HCC}$ patients undergoing TACE: A cross-sectional study in China. Support Care Cancer 21: 475-483, 2013.

8. Chen M, Therneau T, Orsini LS and Qiao YL: Design and rationale of the HCC BRIDGE study in China: A longitudinal, multicenter cohort trial in hepatocellular carcinoma. BMC Gastroenterol 11: 53, 2011.

9. Li GJ, Harrison TJ, Yang JY, Chen QY, Wang XY and Fang ZL: Combined core promoter mutations and pre-S deletion of HBV may not increase the risk of HCC: A geographical epidemiological study in Guangxi, China. Liver Int 33: 936-943, 2013.

10. El-Serag HB and Rudolph KL: Hepatocellular carcinoma: Epidemiology and molecular carcinogenesis. Gastroenterology 132: 2557-2576, 2007.

11. Feng YM, Feng CW, Chen SC and Hsu CD: Unexpected remission of hepatocellular carcinoma (HCC) with lung metastasis to the combination therapy of thalidomide and cyproheptadine: Report of two cases and a preliminary HCC cell line study. BMJ Case Rep 2012: pii: bcr2012007180, 2012.

12. Yuan JH, Yang F, Wang F, Ma JZ, Guo YJ, Tao QF, Liu F, Pan W, Wang TT, Zhou CC, et al: A long noncoding RNA activated by TGF- $\beta$ promotes the invasion-metastasis cascade in hepatocellular carcinoma. Cancer Cell 25: 666-681, 2014.

13. Hou YQ, Yao Y, Bao YL, Song ZB, Yang C, Gao XL, Zhang WJ, Sun LG, Yu CL, Huang YX, et al: Juglanthraquinone C induces intracellular ROS increase and apoptosis by activating the Akt/Foxo signal pathway in HCC cells. Oxid Med Cell Longev 2016: 4941623, 2016.

14. Wang Y, Huang X, Han J, Zheng W and Ma W: Extract of Perilla frutescens inhibits tumor proliferation of HCC via PI3K/AKT signal pathway. Afr J Tradit Complement Altern Med 10: 251-257, 2012.

15. Serru V, Dessen P, Boucheix C and Rubinstein E: Sequence and expression of seven new tetraspans. Biochim Biophys Acta 1478: 159-163, 2000.

16. Ji ZJ, Wang JL and Chen L: Inhibition of skin squamous cell carcinoma proliferation and promote apoptosis by dual silencing of NET-1 and survivin. Oncol Rep 34: 811-822, 2015.

17. Wu B, Liang X, Jing H, Han X, Sun Y, Guo C, Liu Y and Cheng W: Effect of NET-1 siRNA conjugated sub-micron bubble complex combined with low-frequency ultrasound exposure in gene transfection. Oncotarget 9: 4150-4160, 2017.

18. Zuo Y, Ulu A, Chang JT and Frost JA: Contributions of the RhoA guanine nucleotide exchange factor Net1 to polyoma middle T antigen-mediated mammary gland tumorigenes and metastasis. Breast Cancer Res 20: 41, 2018.

19. Gabitova $\mathrm{G}$ and Burke NJ: Improving healthcare empowerment through breast cancer patient navigation: A mixed methods evaluation in a safety-net setting. BMC Health Serv Res 14: 407, 2014.

20. Wheelock AE, Bock MA, Martin EL, Hwang J, Ernest ML, Rugo HS, Esserman LJ and Melisko ME: SIS.NET: A randomized controlled trial evaluating a web-based system for symptom management after treatment of breast cancer. Cancer 121: 893-899, 2015.

21. Shen SQ, Li K, Zhu N and Nakao A: Expression and clinical significance of NET-1 and PCNA in hepatocellular carcinoma. Med Oncol 25: 341-345, 2008.

22. Fang L, Zhu J, Ma Y, Hong C, Xiao S and Jin L: Neuroepithelial transforming gene 1 functions as a potential prognostic marker for patients with non-small cell lung cancer. Mol Med Rep 12: 7439-7446, 2015.

23. Sun CK, Chua MS, He J and So SK: Suppression of glypican 3 inhibits growth of hepatocellular carcinoma cells through up-regulation of TGF- $\beta 2$. Neoplasia 13: 735-747, 2011. 
24. Bruix J, Sherman M, Llovet JM, Beaugrand M, Lencioni R, Burroughs AK, Christensen E, Pagliaro L, Colombo M and Rodés J; EASL Panel of Experts on HCC: Clinical management of hepatocellular carcinoma. Conclusions of the Barcelona-2000 EASL conference. European association for the study of the liver. J Hepatol 35: 421-430, 2001.

25. Hu L, Lau SH, Tzang CH, Wen JM, Wang W, Xie D, Huang M, Wang Y, Wu MC, Huang JF, et al: Association of Vimentin overexpression and hepatocellular carcinoma metastasis. Oncogene 23: 298-302, 2004.

26. Zhao XL, Sun T, Che N, Sun D, Zhao N, Dong XY, Gu Q, Yao Z and Sun BC: Promotion of hepatocellular carcinoma metastasis through matrix metalloproteinase activation by epithelial-mesenchymal transition regulator Twist1. J Cell Mol Med 15: 691-700, 2011

27. Lauridsen HM, Pellowe AS, Ramanathan A, Liu R, Miller-Jensen K, McNiff JM, Pober JS and Gonzalez AL: Tumor necrosis factor- $\alpha$ and IL-17A activation induces pericyte-mediated basement membrane remodeling in human neutrophilic dermatoses. Am J Pathol 187: 1893-1906, 2017.

28. Ma YF, Chen C, Li D, Liu M, Lv ZW, Ji Y and Xu J: Targeting of interleukin (IL)-17A inhibits PDL1 expression in tumor cells and induces anticancer immunity in an estrogen receptor-negative murine model of breast cancer. Oncotarget 8: 7614-7624, 2017.

29. Xu LL, Li ZJ, Niu XL and Deng WM: The mechanisms of IL-17A on promoting tumor metastasis. Int Rev Immunol 36: 360-369, 2017

30. Li J, Lau GK, Chen L, Dong SS, Lan HY, Huang XR, Li Y, Luk JM, Yuan YF and Guan XY: Interleukin 17A promotes hepatocellular carcinoma metastasis via NF-kB induced matrix metalloproteinases 2 and 9 expression. PLoS One 6: e21816, 2011

31. Tsai WC, Hsu PW, Lai TC, Chau GY, Lin CW, Chen CM, Lin CD, Liao YL, Wang JL, Chau YP, et al: MicroRNA-122, a tumor suppressor microRNA that regulates intrahepatic metastasis of hepatocellular carcinoma. Hepatology 49: 1571-1582, 2009.

32. Ding SJ, Li Y, Shao XX, Zhou H, Zeng R, Tang ZY and Xia QC: Proteome analysis of hepatocellular carcinoma cell strains, MHCC97-H and MHCC97-L, with different metastasis potentials. Proteomics 4: 982-994, 2004.

33. Song P, Bao H, Yu Y, Xue Y, Yun D, Zhang Y, He Y, Liu Y, Liu Q, Lu H, et al: Comprehensive profiling of metastasis-related proteins in paired hepatocellular carcinoma cells with different metastasis potentials. Proteomics Clin Appl 3: 841-852, 2009.

34. Chen L, Wang Z, Zhan X, Li DC, Zhu YY and Zhu J: Association of NET-1 gene expression with human hepatocellular carcinoma. Int J Surg Pathol 15: 346-353, 2007.

35. Bagci EZ, Vodovotz Y, Billiar TR, Ermentrout GB and Bahar I: Bistability in apoptosis: Roles of bax, bcl-2, and mitochondrial permeability transition pores. Biophys J 90: 1546-1559, 2006.

36. Prokop A, Wieder T, Sturm I, Essmann F, Seeger K, Wuchter C, Ludwig WD, Henze G, Dörken B and Daniel PT: Relapse in childhood acute lymphoblastic leukemia is associated with a decrease of the Bax/Bcl-2 ratio and loss of spontaneous caspase-3 processing in vivo. Leukemia 14: 1606-1613, 2000

37. Manero F, Gautier F, Gallenne T, Cauquil N, Grée D, Cartron PF, Geneste O, Grée R, Vallette FM and Juin P: The small organic compound HA14-1 prevents Bcl-2 interaction with Bax to sensitize malignant glioma cells to induction of cell death. Cancer Res 66: 2757-2764, 2006

38. Raisova M, Hossini AM, Eberle J, Riebeling C, Wieder T, Sturm I, Daniel PT, Orfanos CE and Geilen CC: The Bax/Bcl-2 ratio determines the susceptibility of human melanoma cells to CD95/Fas-mediated apoptosis. J Invest Dermatol 117: 333-340, 2001.

39. Del Bufalo D, Biroccio A, Leonetti C and Zupi G: Bcl-2 overexpression enhances the metastatic potential of a human breast cancer line. FASEB J 11: 947-953, 1997.
40. Mukhopadhyay A, Banerjee S, Stafford LJ, Xia C, Liu M and Aggarwal BB: Curcumin-induced suppression of cell proliferation correlates with down-regulation of cyclin D1 expression and CDK4-mediated retinoblastoma protein phosphorylation. Oncogene 21: 8852-8861, 2002

41. Fu M, Wang C, Li Z, Sakamaki T and Pestell RG: Minireview: Cyclin D1: Normal and abnormal functions. Endocrinology 145: 5439-5447, 2004.

42. Aouacheria A, Cunningham KW, Hardwick JM, Palková Z, Powers T, Severin FF and Váchová L: Comment on 'Sterilizing immunity in the lung relies on targeting fungal apoptosis-like programmed cell death'. Science 360: pii: eaar6910, 2018.

43. Shlezinger N, Irmer H, Dhingra S, Beattie SR, Cramer RA, Braus GH, Sharon A and Hohl TM: Response to comment on 'Sterilizing immunity in the lung relies on targeting fungal apoptosis-like programmed cell death'. Science 360: pii: eaas9457, 2018.

44. Le DA, Wu Y, Huang Z, Matsushita K, Plesnila N, Augustinack JC, Hyman BT, Yuan J, Kuida K, Flavell RA and Moskowitz MA: Caspase activation and neuroprotection in caspase-3- deficient mice after in vivo cerebral ischemia and in vitro oxygen glucose deprivation. Proc Natl Acad Sci USA 99: 15188-15193, 2002.

45. Richardson-Burns SM, Kominsky DJ and Tyler KL: Reovirus-induced neuronal apoptosis is mediated by caspase 3 and is associated with the activation of death receptors. J Neurovirol 8: 365-380, 2002.

46. Fu Y, Ye X, Lee M, Rankin G and Chen YC: Prodelphinidins isolated from Chinese bayberry leaves induces apoptosis via the p53-dependent signaling pathways in OVCAR-3 human ovarian cancer cells. Oncol Lett 13: 3210-3218, 2017.

47. Pidugu VR, Yarla NS, Bishayee A, Kalle AM and Satya AK: Novel histone deacetylase 8-selective inhibitor 1,3,4-oxadiazole-alanine hybrid induces apoptosis in breast cancer cells. Apoptosis 22: 1394-1403, 2017.

48. Zhou M, Liu X, Li Z, Huang Q, Li F and Li CY: Caspase-3 regulates the migration, invasion and metastasis of colon cancer cells. Int J Cancer 143: 921-930, 2018.

49. Persad R, Liu C, Wu TT, Houlihan PS, Hamilton SR, Diehl AM and Rashid A: Overexpression of caspase-3 in hepatocellular carcinomas. Mod Pathol 17: 861-867, 2004.

50. Brunet A, Datta SR and Greenberg ME: Transcription-dependent and -independent control of neuronal survival by the PI3K-Akt signaling pathway. Curr Opin Neurobiol 11: 297-305, 2001.

51. Franke TF, Hornik CP, Segev L, Shostak GA and Sugimoto C: PI3K/Akt and apoptosis: Size matters. Oncogene 22: 8983-8998, 2003.

52. Garcia-Echeverria $C$ and Sellers WR: Drug discovery approaches targeting the PI3K/Akt pathway in cancer. Oncogene 27: 5511-5526, 2008

53. Cao J, Lv W, Wang L, Xu J, Yuan P, Huang S, He Z and Hu J: Ricolinostat (ACY-1215) suppresses proliferation and promotes apoptosis in esophageal squamous cell carcinoma via miR-30d/PI3K/AKT/mTOR and ERK pathways. Cell Death Dis 9: 817, 2018 .

54. Leng J, Wang Z, Fu CL, Zhang J, Ren S, Hu JN, Jiang S, Wang YP, Chen $\mathrm{C}$ and $\mathrm{Li} \mathrm{W}$ : $\mathrm{NF}-\kappa \mathrm{B}$ and AMPK/PI3K/Akt signaling pathways are involved in the protective effects of Platycodon grandiflorum saponins against acetaminophen-induced acute hepatotoxicity in mice. Phytother Res 32: 2235-2246, 2018

55. Zhang HW, Hu JJ, Fu RQ, Liu X, Zhang YH, Li J, Liu L, Li YN, Deng Q, Luo QS, et al: Flavonoids inhibit cell proliferation and induce apoptosis and autophagy through downregulation of PI3KgammamediatedPI3K/AKT/mTOR/p70S6K/ULKsignaling pathway in human breast cancer cells. Sci Rep 8: 11255, 2018.

56. Saxena NK, Sharma D, Ding X, Lin S, Marra F, Merlin D and Anania FA: Concomitant activation of the JAK/STAT, PI3K/AKT, and ERK signaling is involved in leptin-mediated promotion of invasion and migration of hepatocellular carcinoma cells. Cancer Res 67: 2497-2507, 2007. 